\title{
SPENDING REVIEW BERBASIS PERFORMANCE-BASED BUDGETING (PBB) TERHADAP APBD KABUPATEN SLEMAN TAHUN 2017-2018
}

\author{
Al Fauzi Rahmat ${ }^{1}$, Fajar Rahmanto ${ }^{2}$, \\ Muchammad Iqbal Firmansyah ${ }^{3}$, Dyah Mutiarin ${ }^{4}$ \\ 1,2,3,4 Program Pascasarjana Magister Ilmu Pemerintahan, Jusuf Kalla School of Government, \\ Universitas Muhammadiyah Yogyakarta, Indonesia \\ Email: al.fauzi.psc19@mail.umy.ac.id
}

\begin{abstract}
Abstrak: Artikel ini bertujuan untuk menganalisis sejauh mana spending review berbasis Performance-Based Budgeting (PBB) terhadap APBD Kabupaten Sleman tahun 2017-2018. Selanjutnya, artikel ini menggunakan metode kualitatif yaitu untuk mengidentifikasi dan menafsirkan sebuah konteks terkait spending review yang perlu di identifikasi secara mendalam. Kemudian, perolahan data dilakukan melalui studi kajian literature (online dan offline). Sebagaimana penggunaan teknik analisis data dalam penelitian ini dilakukan dengan tahapan kodifikasi data, penyajian data dan hasil data penelitian. Hasil penelitin ini menunjukan bahwa kondisi anggaran belanja daerah Pemerintah Kabupaten Sleman Tahun 2017 dan 2018 mengalami kenaikan, namun ditinjau pada sektor anggaran belanja pegawai Pemerintah Kabupaten Sleman mengalami penurunan. Selanjutnya hasil review alokasi yang dilakukan terhadap realisasi anggaran belanja daerah terjadi penghematan anggaran belanja dari tahun 2017 ke 2018. Kemudian, untuk review tolak ukur dan kinerja melalui layanan kesehatan dan pendidikan menunjukan adanya peningkatan angka indeks pembangunan manusia. Lebih lanjut, Analisis Deviasi Kebutuhan menunjukkan dalam dua tahun anggaran Pemerintah Kabupaten Sleman yakni tahun 2017 dan 2018 memiliki tingkat rata-rata deviasi kebutuhan dengan alokasi anggaran belanja daerah sebesar $(11,85 \%)$.
\end{abstract}

Kata kunci: Spending Review; Performance-Based Budgeting; APBD; Kabupaten Sleman

Abstract: This article aims to analyze the extent of spending based on Performance-Based Budgeting (PBB) based Regional Expenditure Budget (APBD) of Sleman Regency in 20172018. Furthermore, this article uses a qualitative method to identify and interpret a context related to spending review that needs to be identified in depth. Therefore, data processing through literature studies (online and offline). As the use of data analysis techniques in this study carried out with the stages of data codification, data presentation and results of research data. The results of this research indicate that condition of regional expenditure budgets of the Sleman Regency Government in 2017 and 2018 has increased, but in terms of expenditure budget sector the Sleman Regency Government employees have decreased. Furthermore, the results of a review of the allocations made to the realization of the regional expenditure budget savings spending occurred from 2017 to 2018. In addition, for a review of benchmarks and performance through health and education services showed an increase in the index of human development. Moreover, the Need Deviation Analysis shows that in the two fiscal years the Sleman Regency Government, namely 2017 and 2018, has an average deviation of needs with a regional budget allocation of (11.85\%).

Keywords: Spending Review; Performance-based Budget; Regional Expenditure Budget; Sleman Regency 


\section{PENDAHULUAN}

Pasca era reformasi di Indonesia tahun 1998-1999 telah memberikan dampak pada tuntutan untuk transparansi di seluruh sektor sistem penyelenggaraan pemerintah, termasuk transparansi dalam pengelolaan keuangan daerah (Ledo \& Ayem, 2017). Hal ini di pandang oleh (Pratama, Abdurahim, \& Sofyani, 2018) bahwa isu transparansi anggaran masih menjadi permasalahan utama di sektor publik, terutama pada penyelenggaran pemerintahan daerah, sebagaimana dalam (www.kompas.com, 2017) menilai kinerja pemerintah daerah saat ini masih bernilai C (cukup). Sehingga, besarnya tuntutan terhadap peningkatan sangat diperlukan dalam merespon berbagai hal seperti kualitas pelayanan publik, transparansi, dan juga akuntabilitas publik yang mendorong pemerintah daerah agar mampu menerapkan sistem pengelolaan anggaran berbasis kinerja dengan masksimal (Wijayanti, Rahman, \& Nurpratiwi, 2012). Kurang maksimalnya kinerja pemerintah daerah dalam pengelolaan keuangan disebabkan masih terjadi ketidakpahaman terhadap proses penganggaran kinerja terutama pada proses penetapan indikator kinerja yang terisi dalam Rencana Kerja Anggaran (Pratama et al., 2018), sehingga dalam (Prakoso, 2017) menuntut pihak pemerintah daerah untuk mampu melaksanakan penetapan indikator tersebut, dengan demikian mampu memberikan ruang penghematan anggaran di beberapa sektor yang dipandang sebelumnya mengalami inefisinsi dalam suatu anggaran.

Menurut (Parhusip, 2016) bahwa dari tahun 2013, pemerintah Indonesia telah mengawali penggunaan spending review dengan tujuan untuk mengidentifikasi inefisiensi belanja dan memperlebar ruang fiscal, selain itu dalam (Luthfia \& Siregar, 2016) bertujuan untuk mencegah ketidakefisienan penggunaan anggaran pemerintah yang tidak mampu dikontrol oleh pemerintah yang memiliki efek negatif serta tidak signifikannya tehadap implementasi program. Kemudian, menurut (Rachmandiansyah, 2015) kehadiran spending review dipandang sebagai mekanisme dalam mengatasi masalah dalam perencanaan anggaran dan masalah pelaksanaan anggaran. Lebih lanjut, menurut (Octariani, 2017) masalah tersebut dimaksudkan ketika pemerintah mengalami suatu manajemen luaran (output) yang tidak terkendali dan tidak sesuai dengan proses perencanaan awal, sehingga perlu teknik dalam mempersiapkan mekanisme peninjauan terhadap belanja. Sebagaimana hal tersebut dinilai sangat penting untuk memantau tingkat efektivitas anggaran, sehingga sangat mudah untuk mendefinisikan dengan jelas tujuan, sasaran, hasil dan manfaat yang dapat diperoleh dari setiap program yang ditetapkan (Khaerah \& Mutiarin, 2016). Dengan demikian, hal tersebut mampu meningkatkan efektifitas dan efisiensi anggaran serta dapat digunakan sebagai pengeluaran atau meningkatkan anggaran di sektor lain (Robinson, 2013). Oleh karena itu, penerapan spending review di Indonesia merupakan suatu usaha untuk menemukan pilihanpilihan terbaik dalam penghematan anggaran dengan memperbaki kualitas anggaran yang sudah ada (Parhusip, 2016).

Kemudian, diimplementasikannya UU No. 32/2004 tentang Pemerintah Daerah dan UU No.33/2004 tentang Perimbangan Keuangan Pusat dan Daerah telah memberikan sebuah dampak yang sangat signifikan terhadap tata hubungan pemerintahan dan manajemen keuangan terutama dalam pengelolaan anggaran di daerah, di mana membuat APBD yang disusun berdasarkan pendekatan kinerja, system anggaran yang outputnya mengutamakan 
capaian hasil kerja dari perencanaan alokasi anggaran yang telah ditetapkan (Verasvera, 2016). Sehingga, hal ini untuk mewujudkan pencapaian prestasi kerja dilakukan dengan memperhatikan kemampuan sumber pendanaan yang dikeluarkan dan hasil keluaran dari program kegiatan yang telah direncanakan, dikenal dengan istilah Anggaran Berbasis Kinerja $(\mathrm{ABK})$, dimana anggaran yang disususun tersebut berorientasi pada target kinerja (Dwiputrianti, 2012). Dengan demikian, dalam menguraikan anggaran, pemerintah harus memanfaatkan dana secara optimal sesuai dengan program atau kebijakan yang disetujui bersama (Mujiono \& Mutiarin, 2019).

Anggaran berbasis kinerja dibuat dengan berlandaskan pada Rencana Kerja Tahunan (RKT) yang telah dijabarkan ke dalam Rencana Kerja Anggaran (RKA) dalam rangka mewujudkan penggunaan sumber anggaran yang ada dengan efektif dan efisien terhadap capaian hasil kegiatan (Dwiputrianti, 2012). Sehingga, penganggaran berbasis kinerja mengutamakan upaya pencapaian hasil kerja dari perencanaan alokasi biaya yang ditetapkan (Sudaryanti, 2013). Oleh karena itu, penerapan anggaran berbasis kinerja yang baik akan berdampak pada semakin baik pula akuntabilitas publik dari suatu organisasi pemerintah (Safaruddin \& Basri, 2016). Sebagaimana efektivitas penggunaan anggaran berbasis kinerja tersebut memiliki implikasi yang baik dalam penyerapan anggaran (Pratama et al., 2018).

Dengan demikian, penerapan anggaran berbasis kinerja dapat memberikan perubahan yang signifikan terhadap penyusunan anggaran yang sesuai dengan kebutuhan sehingga penggunaan anggaran menjadi efektif dan efisien (Astutiningrum, Djamhuri, \& Prihatiningtias, 2014). Sebagai tambahan bahwa pengelolaan keuangan daerah yang dikelola oleh pemerintah menjadi lebih ekonomis dan efisien setelah menggunakan anggaran berbasis kinerja (Kurrohman, 2013). Lebih lanjut, keberhasilan pemerintah daerah dalam mengelola keuangan daerah menunjukkan baiknya suatu kinerja keuangan dari suatu pemerintah daerah (Sari \& Mustanda, 2019). Sebagaimana menurut Sulistio (2010) bahwa anggaran berbasis kinerja merupakan system anggaran yang menghubungkan output dan outcome yang akan dicapai dengan memberikan penekanan pada efektifitas dan efisiensi alokasi penggunaan anggaran (Nanda \& Darwanis, 2016).

Anggaran menurut Mardiasmo (2009) adalah pernyataan yang terkait dengan estimasi kinerja yang akan dicapai dalam periode waktu tertentu yang ditunjukan dengan bentuk ukuran finansial (Nanda \& Darwanis, 2016). Kemudian, anggaran pada sektor pemerintah merupakan pertanggungjawaban atas pengelolaan dana public dengan program kerja atau kegiatan yang memanfaatkan dana publik (Pratama et al., 2018). Sesuai dengan Peraturan Pemerintah Republik Indonesia Nomor 58 Tahun 2005 tentang Pengelolaan Keuangan Daerah, pelaksanaan belanja daerah digunakan untuk melaksanakan urusan pemerintahan yang menjadi kewenangan daerah baik tingkat provinsi atau kabupaten/kota yang meliputi urusan wajib dan urusan pilihan sesuai ketentuan perundangan (Setiawan, 2017). Untuk anggaran belanja pemerintah daerah Kabupaten Sleman secara umum dapat dilihat pada tabel berikut: 
ISSN 2088-7469 (Paper) ISSN 2407-6864 (Online)

Volume 10 Nomor 2 (2020)

Tabel 1. Anggaran Belanja Pemerintah Daerah Kabupaten Sleman Tahun 2017 Dan 2018

\begin{tabular}{|l|l|r|r|}
\hline No & \multicolumn{1}{|c|}{ Item } & \multicolumn{1}{c|}{ Tahun $\mathbf{2 0 1 7}$} & \multicolumn{1}{c|}{ Tahun 2018 } \\
\hline $\mathbf{2}$ & Belanja Daerah & $\mathbf{2 . 6 1 5 . 3 4 3 . 5 3 3 . 8 6 3 , 3 1}$ & $\mathbf{2 . 6 2 7 . 2 9 6 . 3 4 5 . 9 2 6 , 3 0}$ \\
\hline $\mathbf{2 . 1}$ & Belanja Tidak Langsung & $\mathbf{1 . 4 6 1 . 0 4 1 . 3 4 4 . 5 2 7 , 2 9}$ & $\mathbf{1 . 4 2 1 . 5 1 3 . 8 2 0 . 0 7 2 , 3 0}$ \\
\hline 2.1 .1 & Belanja Pegawai & $1.098 .457 .489 .596,69$ & $1.057 .009 .062 .232,30$ \\
\hline 2.1 .2 & Belanja Bunga & $3.106 .423 .611,00$ & $1.870 .801 .224,00$ \\
\hline 2.1 .3 & Belanja Hibah & $42.967 .387 .300,00$ & $54.066 .118 .680,00$ \\
\hline 2.1 .4 & Belanja Bantuan Sosial & $44.435 .823 .005,80$ & $32.735 .000 .000,00$ \\
\hline 2.1 .5 & $\begin{array}{l}\text { Belanja Bagi Hasil Kepada } \\
\text { Provinsi/Kab/Kota, Pemerintah } \\
\text { Desa }\end{array}$ & & $52.040 .168 .865,00$ \\
\hline 2.1 .6 & $\begin{array}{l}\text { Belanja Bagi Hasil Kepada } \\
\text { Provinsi/Kab/Kota, Pemerintah }\end{array}$ & $218.865 .611 .722,80$ & $220.273 .517 .190,00$ \\
& Desa Dan Partai Politik & & \\
\hline 2.1 .7 & Belanja Tidak Terduga & $\mathbf{1 . 1 5 4 . 3 0 2 . 1 8 9 . 3 3 6 , 0 2}$ & $\mathbf{1 . 2 0 5 . 7 8 2 . 5 2 5 . 8 5 4}$ \\
\hline $\mathbf{2 . 2}$ & Belanja Langsung & $159.181 .422 .090,20$ & $199.531 .932 .741,00$ \\
\hline 2.2 .1 & Belanja Pegawai & $607.606 .402 .536,73$ & $641.612 .494 .959,00$ \\
\hline 2.2 .2 & Belanja Barang Dan Jasa & $387.514 .364 .709,09$ & $364.638 .098 .154,00$ \\
\hline 2.2 .3 & Belanja Modal & & \\
\hline
\end{tabular}

Sumber: APBD Sleman, 2017 Dan 2018

Dari tabel tersebut diketahui besaran anggaran belanja daerah Kabupaten Sleman mengalami peningkatan yang tidak begitu signifikan yakni dari 2.615 milyar rupiah tahun 2017 menjadi 2.627 milyar rupiah di tahun 2018. Adapun untuk komposisi belanja daerah yang terdiri dari belanja tidak langsung mengalami penurunan sebesar 40 milyar rupiah dari 1.461 milyar rupiah tahun 2017 menjadi 1.421 milyar rupiah pada 2018 atau 0,03\%. Terjadinya penurunan anggaran belanja tidak langsung tersebut juga dipengaruhi oleh penurunan anggaran belanja pegawai yang memiliki alokasi terbesar pada belanja daerah dimana dari 1.098 milyar rupiah tahun 2017 menjadi 1.057 milyar rupiah tahun 2018 atau mengalami penurunan sebesar $0,04 \%$. Selain itu juga didukung oleh penurunan anggaran pada belanja bunga dari 3,1 milyar menjadi 1,87 milyar dan belanja bantuan social dari 44,4 milyar rupiah 32,7 milyar rupiah pada tahun 2018 dengan prosentase penurunan untuk belanja bunga sebesar $0,40 \%$ (1,23 milyar rupiah), belanja bantuan social sebesar $0,26 \%$ (11,7 milyar rupiah). Sedangkan untuk anggaran belanja langsung mengalami peningkatan sebesar 0,04\% dari 1.154 milyar rupiah pada 2017 menjadi 1.205 milyar rupiah pada 2018. Mayoritas anggaran belanja langsung dialokasikan untuk belanja barang dan jasa yang mencapai sekitar 600an milyar rupiah dalam dua tahun anggaran tersebut. Kemudian untuk realsiasi penggunaan anggaran belanja daerah tahun 2017 dan 2018 seperti pada tabel berikut: 
ISSN 2088-7469 (Paper) ISSN 2407-6864 (Online)

Volume 10 Nomor 2 (2020)

Tabel 2. Realisasi Anggaran Belanja Daerah Kabupaten Sleman

Tahun 2017-2018

\begin{tabular}{|l|l|r|r|r|r|}
\hline \multirow{2}{*}{ No } & \multicolumn{1}{|c|}{ Item } & \multicolumn{2}{|c|}{ Tahun 2017 } & \multicolumn{2}{c|}{ Tahun 2018 } \\
\cline { 3 - 6 } & \multicolumn{1}{|c|}{ Anggaran } & \multicolumn{1}{c|}{ Realisasi } & \multicolumn{1}{c|}{ Anggaran } & \multicolumn{1}{c|}{ Realisasi } \\
\hline $\mathbf{2}$ & Belanja Daerah & $2.572 .322 .684 .054,77$ & $2.226 .283 .121 .962,72$ & $2.615 .171 .527 .715,28$ & $2.298 .131 .055 .803,06$ \\
\hline $\mathbf{2 . 1}$ & $\begin{array}{l}\text { Belanja } \\
\text { Operasi }\end{array}$ & $2.106 .893 .115 .773,28$ & $1.844 .485 .148 .134,00$ & $2.125 .682 .316 .998,00$ & $1.886 .682 .958 .936,50$ \\
\hline 2.1 .1 & Belanja Pegawai & $1.303 .489 .836 .367,62$ & $1.128 .501 .908 .291,18$ & $1.288 .464 .045 .146,56$ & $1.136 .436 .322 .475,00$ \\
\hline 2.1 .2 & $\begin{array}{l}\text { Belanja Barang } \\
\text { dan Jasa }\end{array}$ & $663.500 .298 .219,86$ & $590.694 .164 .959,82$ & $709.638 .938 .542,80$ & $632.023 .010 .894,75$ \\
\hline 2.1 .3 & Bunga & $2.678 .741 .220,00$ & $2.358 .580 .867,00$ & $1.870 .801 .224,00$ & $1.574 .098 .880,00$ \\
\hline 2.1 .4 & Hibah & $92.493 .416 .920,00$ & $88.235 .807 .916,00$ & $91.368 .532 .085,00$ & $87.536 .588 .786,75$ \\
\hline 2.1 .5 & Bantuan Sosial & $44.730 .823 .005,80$ & $34.694 .686 .100,00$ & $34.340 .000 .000,00$ & $29.112 .937 .900,00$ \\
\hline $\mathbf{2 . 2}$ & Belanja Modal & $459.664 .344 .876,46$ & $380.627 .054 .895,72$ & $476.900 .428 .379,00$ & $411.312 .404 .568,56$ \\
\hline 2.2 .1 & Belanja Tanah & $70.497 .422 .713,00$ & $24.499 .277 .856,00$ & $37.026 .932 .088,00$ & $23.968 .613 .921,26$ \\
\hline 2.2 .2 & $\begin{array}{l}\text { Belanja Peralatan } \\
\text { dan Mesin }\end{array}$ & $85.286 .676 .848,46$ & $78.491 .177 .590,53$ & $109.534 .340 .870,00$ & $103.267 .579 .893,95$ \\
\hline 2.2 .3 & $\begin{array}{l}\text { Belanja Gedung } \\
\text { dan Bangunan }\end{array}$ & $129.942 .887 .080,00$ & $121.377 .512 .878,19$ & $98.361 .635 .249,00$ & $86.964 .485 .418,53$ \\
\hline 2.2 .4 & $\begin{array}{l}\text { Belanja Jalan, } \\
\text { Irigasi dan }\end{array}$ & $129.983 .390 .320,00$ & $119.460 .878 .630,00$ & $183.990 .415 .156,00$ & $154.464 .420 .371,00$ \\
\hline Jaringan & $\begin{array}{l}\text { Belanja Aset } \\
\text { Tetap Lainnya }\end{array}$ & $43.951 .965 .935,00$ & $36.798 .207 .941,00$ & $47.987 .105 .016,00$ & $42.647 .3014 .963,82$ \\
\hline $\mathbf{2 . 3}$ & $\begin{array}{l}\text { Belanja Tak } \\
\text { Terduga }\end{array}$ & $5.765 .223 .445,03$ & $1.170 .918 .933,00$ & $12.588 .782 .337,92$ & $135.692 .298,00$ \\
\hline
\end{tabular}

Sumber: Laporan Realisasi APBD Sleman, 2017-2018

Dari tabel tersebut dapat dilihat untuk kondisi belanja daerah di Kabupaten Sleman pada tahun anggaran 2017 dan tahun anggaran 2018 mengalami peningkatan sebesar 43 milyar rupiah dengan capaian realisasi anggaran 2.226 milyar (2017) meningkat menjadi 2.298 milyar (2018) atau relisasi anggaran terjadi peningkatan sebesar 72 milyar rupiah. Anggaran belanja daerah tersebut digunanakan ke dalam tiga sekup belanja yakni belanja operational, belanja modal dan belanja tak terduga dengan alokasi terbesar untuk belanja operasional yang mencapai 2.106 milyar (2017) dengan realisasi 1.844 milyar dan 2.125 milyar (2018) dengan realisasi mencapai 1.886 milyar. Dari belanja operasional tersebut mayoritas digunakan untuk mencukupi belanja pegawai sebesar 1.303 milyar (2017) dan menurun menjadi 1.288 milyar (2018), akan tetapi realisasi mengalami peningkatan sebesar 8 milyar dari 1.128 milyar menjadi 1.136 milyar di tahun 2018. Kemudian untuk belanja modal digunakan untuk belanja tanah, belanja peralatan dan mesin, belanja Gedung dan bangunan, belanja jalan irigasi dan jaringan serta belanja asset lainnya dimana alokasi terbesar digunakan untuk belanja jalan irigasi dan jaringan sebesar 129,98 milyar (2017) mengalami peningkatan 54,01 milyar pada tahun 2018 menjadi sebesar 183,99 milyar dengan realisasinya 119,46 milyar pada 2017 menjadi 154,46 milyar tahun 2018.

\section{Tata Kelola Anggaran Publik Di Indoneisa}

Anggaran adalah suatu rencana kegiatan yang diwujudkan dalam bentuk finansial yang mana meliputi suatu usulan pengeluaran yang diperkirakan untuk satu periode atau 
waktu yang kemudian dikembangkan dalam rangka melayani berbagai macam tujuan termasuk pengendalian keuangan, rencana manajemen, dan juga prioritas dari pengguna dana serta pertanggungjawaban kepada publik (Safaruddin \& Basri, 2016). Sebagai bagian dari reformasi manajemen sektor publik, reformasi anggaran mengacu pada perubahan sistem penganggaran dalam pemerintahan dengan melibatkan perencanaan keuangan publik dengan perkiraan pendapatan dan pengeluaran untuk periode tertentu (Prakoso, 2017).

Sehingga diterapkan reformasi manajemen keuangan menjadikan penganggaran di negara Indonesia dilakukan berbasis kinerja yakni penyususnan anggaran didasarkan pada kinerja atau output/ outcome (Parhusip, 2016). Lebih lanjut, penyusunan anggaran dengan pendekatan kinerja memberikan konsekuensi terhadap pengalokasian setiap anggaran yang direncanakan yang mana harus dikaitkan dengan tingkat pelayanan dan hasil yang diharapkan agar dapat dicapai (Sudaryanti, 2013).

Menurut (Safaruddin \& Basri, 2016) adanya manfaat dari diterapkannya anggaran berbasis kinerja oleh pemerintah daerah meliputi:

1. Bagi Masyarakat

Merupakan pernyataan pembangunan yang dinyatakan pemerintah daerah untuk menjawab setiap kebutuhan, tuntutan atau aspirasi masyarakat guna mencapai kesejahteraan masyarakat. Kebutuhan masyarakat tak terbatas, sedangkan sumber daya yang tersedia terbatas.

2. Bagi Kepala Daerah selaku Manajemen

Sebagai alat manajemen untuk mengendalikan dan mengarahkan setiap aktivitas dalam pemerintah daerah agar senantiasa mengacu kepada rencana yang dibuat.

3. Bagi Aparatur dan Satuan Kerja

Sebagai sarana untuk mendorong setiap satuan kerja untuk lebih selektif dalam merencanakan aktivitas berdasarkan skala prioritas daerah, tugas pokok dan fungsi, tujuan serta sasaran, serta terjaminnya sinkronisasi aktivitas dan terhindarnya tumpang tindih aktivitas.

4. Bagi Stakeholder yang diwakili oleh DPRD

Sebagai media komunikasi dan pertanggungjawaban tentang keberhasilan maupun kegagalan pelaksanaan misi pemerintah daerah dalam mencapai tujuan dan sasaran yang telah ditetapkan, serta menerangkan kinerja yang dilaksanakan.

\section{Spending Review Di Indonesia}

Spending review (ulasan pengeluaran), menurut Robinson (2013) merupakan upaya yang dilakukan pemerintah dalam proses penghematan anggaran dengan melihat secara menyeluruh atas pengeluaran yang akan digunakan sebagai pengeluaran dasar (Prakoso, 2017). Secara umum definisi spending review merupakan salah satu instrument dalam reformasi fiskal untuk menciptakan ruang fiskal dengan cara mengurangi atau mengalokasikan kembali belanja anggaran yang disebabkan adanya perubahan penentuan prioritas dan permintaan peningkatan pelayanan atau peningkatan indicator kinerja (Parhusip, 2016). Sehingga dapat dikatakan spending review pada dasarnya merupakan bagian dari system penganggaran berbasis kinerja karena hasil informasi yang disajikan digunakan untuk 
pengambilan keputusan dalam menetapkan anggaran (Parhusip, 2016). Kemudian spending review memiliki dua tujuan utama yakni memberikan kontrol penuh kepada stakeholders dalam pembuat keputusan negara atas pengeluaran pemerintah dan untuk memberikan prioritas pengeluaran dana publik (Prakoso, 2017). Selanjutnya Robinson (2013) menyatakan spending review dapat diklasifikasikan menjadi dua kategori; 1) Pengematan Efisiensi, upaya ini dilakukan dengan mengurangi pengeluaran melalui perubahan cara dalam memberikan pelayanan dimana dengan mengurangi biaya pelaksanaan pelayanan tetapi hasil dari kualitas layanan yang diberikan tetap sama; 2) Penghematan Strategis, dilakukan dengan memotong anggaran yang harus dialokasikan kepada masyarakat.

Di Indonesia spending review mulai diterapkan pada tahun 2013 dengan Kementrian Keuangan sebagai institusi yang memimpin (leading institution), tujuannya untuk mencegah terjadinya inefisiensi penggunaan anggaran dengan cara melakukan identifikasi terhadap program/kegiatan agar tidak berulang pada tahun anggaran berikutnya, identifikasi potensi ruang fiskal, melakukan pengukuran belanja pemerintah dari segi ekonomis atau efisiensi atau efektivitas (Parhusip, 2016). Untuk metode utama yang dapat digunakan dalam melakukan spending review menurut (Schiavo-Campo, 1999; Curristine, 2005) diantaranya benchmarking, pengukuran kinerja dan evaluasi (Parhusip, 2016). Sedangkan di Indonesia metode untuk melakukan spending review terhadap anggaran dilihat dari ; 1) Review Alokasi, untuk mengidentifikasi potensi ruang fiscal dengan cara identifikasi indikasi inefisiensi, duplikasi dan identifikasi belanja agar kegiatan atau program tidak terulang (einmaleg); 2) Review Tolak Ukur Target dan Kinerja, upaya yang dilakukan dengan mengelompokkan unitunit sejenis sehingga dapat diketahui kinerja terbaik dari unit tersebut dalam satu kelompok unit yang sama dan mengukur selisih antara kinerja suatu unit dengan kinerja terbaik sebagai inefisiensi atau sering dikenal dengan istilah metode benchmarking; 3) Analisis Deviasi Kebutuhan, yaitu metode untuk menganalisis deviasi kebutuhan dengan cara menghitung deviasi antara realisasi belanja-belanja operasional satuan kerja dibandingkan dengan ratarata realisasi belanja operasional selama satu tahun (Parhusip, 2016).

\section{Performance Based Budgeting (PBB)}

Anggaran berbasis kinerja merupakan output atau prestasi kerja dari kegiatan yang akan dilaksanakan dengan orientasi penyusunan anggaran diarahkan pada efektifitas, efisiensi dan ekonomis (Pratama et al., 2018). Sedangkan menurut Sancoko (2008) prinsip anggaran berbasis kinerja adalah anggaran yang memiliki hubungan pengeluaran negara dengan hasil yang diharapkan (output dan outcome) (Kurrohman, 2013). PBB adalah model anggaran yang memiliki fokus pada alokasi sumber daya berdasarkan kinerja dari suatu program/kegiatan (Prakoso, 2017). PBB dibuat untuk menciptakan efisiensi, efektivitas dan akuntabilitas penggunaan anggaran belanja publik, dengan output dan outcome sesuai tingkatan prioritas pembangunan sehingga semua pengeluaran anggaran mampu untuk dipertanggungjawabkan secara transparan kepada public (Kurrohman, 2013). Menurut Kong (2005), ada tiga jenis orientasi pengukuran kinerja di dalam penganggaran (Prakoso, 2017): 
1) Berfokus pada sumber daya

Dimana anggaran pemerintah memiliki fokus hanya untuk mengukur kinerja sumber daya input, misal keuangan atau sumber daya lain.

2) Berfokus pada organisasi

Dimana anggaran pemerintah juga fokus pada kinerja proses dan hasil organisasi, termasuk keuangan, layanan dan program dan/atau kegiatan.

3) Berfokus pada pelanggan

Anggaran pemerintah memberikan tekanan pada langkah kinerja (kepuasan, kualitas layanan dan hasil).

Sehingga dapat diartikan secara umum, Performance Based Budgeting adalah system penganggaran yang memiliki fokus terhadap keterkaitan antara pendanaan dengan hasil yang diaharapkan temasuk pada efisiensi pencapaian hasil sehingga akan mendorong prinsip transparansi, efisiensi, evektifitas dan akuntabilitas (Kurrohman, 2013).

Anggaran berbasis kinerja bertujuan untuk mendorong peningkatan efektifitas dan efisiensi pengeluaran publik dengan cara menghubungkan penganggaran organisasi sektor publik dengan output yang ingin dicapai melalui penggunaan informasi kinerja (Robinson \& Last, 2009). Kemudian menurut Direktorat Pengawasan Penyelenggaraan Keuangan Daerah (2005) tujuan dari anggaran berbasis kinerja adalah untuk (Nanda \& Darwanis, 2016):

1) Mengaitkan antara pendanaan dan kinerja yang akan dicapai.

2) Meningkatkan efisiensi dan transparansi dalam hal pelaksanaan pengelolaan anggaran.

3) Meningkatkan akuntabilitas dan fleksibilitas dalam hal pelaksanakan pengelolaan anggaran.

Menurut Bappenas (2009), indikator kinerja memberikan gambaran tentang apa yang ingin diukur dan untuk menentukan apakah tujuan sudah tercapai, dimana ukuran indicator sebagai instrument penilaian terhadap belanja pemerintah sebagai berikut (Nanda \& Darwanis, 2016):

1) Masukan (input)

Merupakan ukuran kinerja yang berdasarkan pendanaan, sumber daya manusia, material, waktu, teknologi dan lain-lain yang digunakan untuk melaksanakan program dan kegiatan.

2) Keluaran (output)

Tolak ukur kinerja berdasarkan barang/jasa yang dihasilkan dari program dan kegiatan sesuai dengan input yang digunakan.

3) Hasil (outcome)

Ukuran kinerja dengan tingkat keberhasilan yang akan dicapai berdasarkan output program yang sudah dilaksanakan.

4) Manfaat (benefit)

Adalah tolak ukur kinerja berdasarkan tingkat kemanfaatan yang dapat dirasakan bagi masyarakat dan juga pemerintah.

5) Dampak (impact) 
ISSN 2088-7469 (Paper) ISSN 2407-6864 (Online)

Volume 10 Nomor 2 (2020)

Merupakan tolak ukur kinerja berdasarkan implikasinya terhadap kondisi makro yang ingin dicapai dari manfaat tersebut.

\section{Gambar 1. Kerangka Teori Spending Review Berbasis PBB}

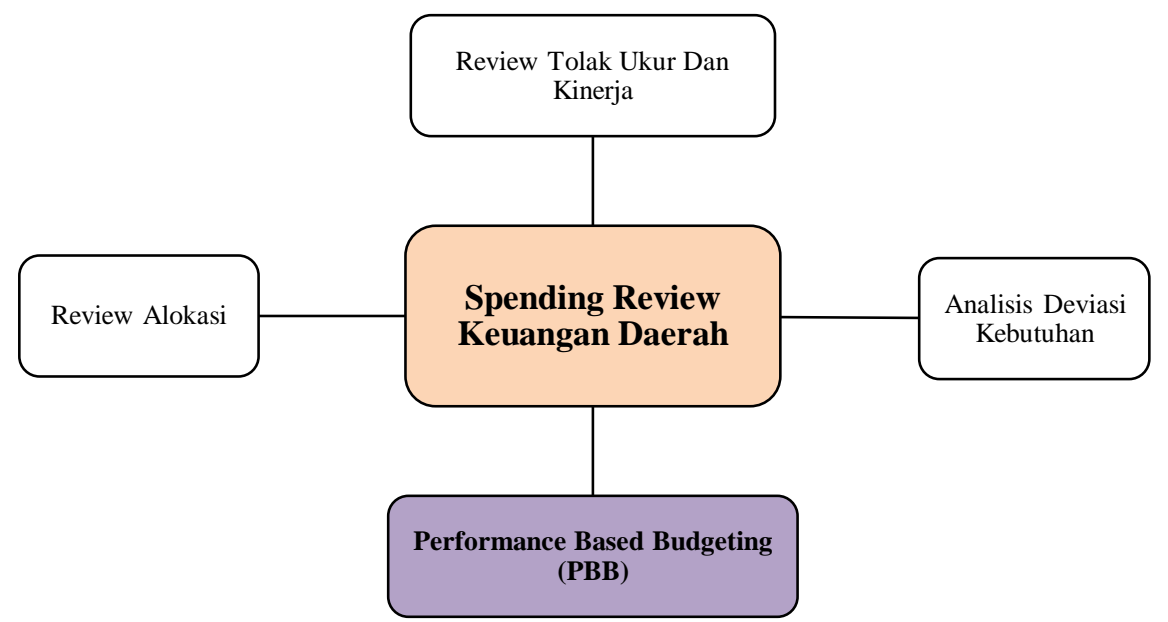

Sumber: Analisa Penulis, (Rahmat, et al. 2020)

\section{METODE PENELITIAN}

Artikel ini menggunakan penelitian kualittaif, menurut (Anggito \& Setiawan, 2018) bahwa penelitian kualitatif merupakan pengumpulan data dengan latar alamiah, kemudian menafsirkan lebh lanjut dan mengintreprestasikan fenomena tersebut. Selain itu, menurut (Creswell, 2015) alasan pemilihan penelitian kualitatif karena adanya suatu permasalahan penelitian yang perlu di identifikasi secara mendalam dan diperlukan pemahaman yang lebih detail terkait permasalahan tersebut. Adanya permasalahan dalam pelaksanaan spending review untuk melakukan identifikasi terhadap kualitas pengelolaan anggaran pengeluaran pemerintah daerah memerlukan pemahaman yang lebih mendalam dan komperhensif dengan menggali esensi/ konteks dari objek permasalahan yang tidak diperoleh dari penelitian seacar kuantitatif.

Kemudian data penelitian diperoleh secara studi literatur melalui metode online maupun offline yang berupa dokumen, literatur, artikel, jurnal, dokumentasi, arsip publikasi kegiatan, tautan situs internet, dan lainnya yang terkait objek penelitian dan mendukung analisis penelitian. Selanjutnya, teknik analisis data kualitatif dilakukan dengan tahapan kodifikasi data, penyajian data dan penarikan kesimpulan (Afrizal, 2015). Dalam penelitian ini penggunaan teknik analisis data dilakukan dengan tahapan kodifikasi data penelitian, penyajian data dan hasil penelitian, memberikan kesimpulan penelitian yang selanjutnya dilakukan intepretasi atas hasil penelitian. 
ISSN 2088-7469 (Paper) ISSN 2407-6864 (Online)

Volume 10 Nomor 2 (2020)

\section{HASIL DAN PEMBAHASAN}

\section{Kondisi Anggaran Belanja Daerah Secara Umum}

Menurut Permendagri No.13 Tahun 2006 tentang Pedoman Pengelolaan Keuangan Daerah dan telah diperbarui lagi dengan Permendagri No.21 Tahun 2011 menjelaskan struktur APBD adalah satu kesatuan rencana kegiatan dan keuangan yang terdiri dari pendapatan daerah, belanja daerah dan pembiayaan daerah. Dilihat dari aspek belanja daerah maka dapat dikelompokkan menjadi dua jenis yakni ; 1) Belanja Tidak Langsung (BTL) yaitu belanja yang tidak terkait dengan program dan kegiatan; 2)Belanja Langsung (BL) merupakan belanja yang terkait langsung dengan program dan kegiatan. Untuk di Kabupaten Sleman anggaran belanja daerah dalam tahun 2017-2018 mengalami kenaikan dan anggaran belanja didominasi untuk Belanja Tidak Langsung seperti dalam gambar berikut:

\section{Gambar 2.}

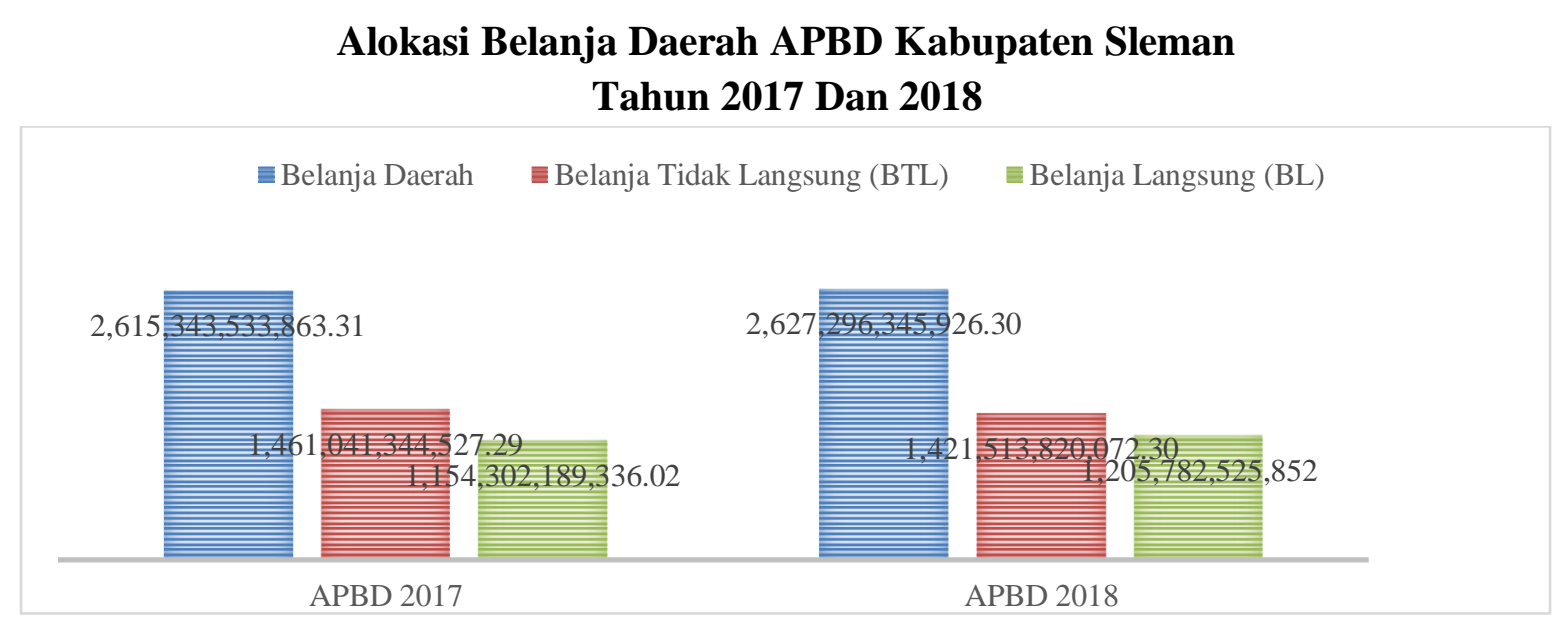

Sumber: Diolah dari APBD Kab.Sleman Tahun 2017 \& 2018

Dari gambar 1. tersebut dapat diketahui untuk belanja daerah di Kabupaten Sleman dari 2017 sebesar 2.615 milyar rupiah mengalami kenaikan pada tahun 2018 menjadi 2.627 milyar rupiah atau meningkat $0,45 \%$. Untuk Belanja Tidak Langsung (BTL) mengalami penurunan $(1,75 \%)$ atau sebesar 39,5 milyar rupiah dari tahun 2017 sampai 2018, sedangkan dari Belanja Langsung (BL) sebaliknya mengalami peningkatan yakni sebesar $(1,75 \%)$ atau sebesar 51,4 milyar rupiah. Kemudian untuk anggaran belanja Kabupaten Sleman tahun 2017-2018 digunakan untuk BTL dengan rata-rata mencapai 1.441 milyar rupiah (54,98\%), lebih tinggi dari BL yang rata-ratanya mencapai angka 1.180 milyar rupiah $(45,02 \%)$. Dari keseluruhan total anggaran belanja daerah tersebut, mayoritas anggaran dialokasikan untuk kebutuhan belanja pegawai baik pada BL maupun pada BTL dengan rata-rata mencapai 1.257 milyar rupiah atau sebesar 47,96\% dari rata-rata total keseluruhan anggaran belanja daerah tahun 2017-2018. Belanja pegawai tahun 2017 yang mencapai angka sekitar 1.257,6 milyar rupiah $(48,09 \%)$ mengalami penurunan menjadi sekitar $1.256,5$ milyar rupiah $(47,83 \%)$ pada tahun 2018 sehingga pemerintah daerah dalam hal ini melakukan efisiensi anggaran untuk belanja pegawai sebesar 0,26\% atau sekitar 1,1 milyar rupiah dalam dua tahun anggaran. Hal tersebut menjadi relevan dikarenakan terjadi penurunan jumlah pegawai di lingkungan pemerintah 
daerah Kabupaten Sleman dari 9.428 orang pegawai di tahun 2017 menjadi 8.834 orang pegawai di tahun 2018 atau berkurang 594 orang pegawai $(6,3 \%)$ dikarenakan sudah masuk purna tugas (LKJIP Kab.Sleman, 2017-2018). Adanya dugaan mark-up anggaran belanja pada proses penyusunan APBD karena untuk belanja pegawai bersifat pasti dan terukur (Sigiro, 2016). Di lain sisi, kemampuan keuangan daerah dengan membandingkan anggaran belanja apabila jumlah belanja lebih besar daripada jumlah pendapatan daerah dalam APBD maka akan menyebabkan terjadinya defisit anggaran setiap tahunnya (Sigiro, 2016). Untuk menekan terjadinya defisit anggaran yang lebih besar maka pemerintah daerah perlu berupaya melakukan efisiensi terhadap alokasi belanja daerah yang ditetapkan dalam APBD.

\section{Spending Review Belanja Daerah}

Spending review menurut Robinson (2013), merupakan alat untuk mendorong peningkatan pada prioritas pengeluaran (efisensi alokatid) yang dapat digunakan dalam mengamankan proses realokasi sumber daya pemerintah dalam menmberikan pelayanan publik yang maksimal (Prakoso, 2017). Selanjutnya menurut Dunn (2015), spending review merupakan cara yang paling baik dalam kerangka konsolidasi fiskal sebagai metode evaluasi yang digunakan oleh pemerintah untuk analisis kebijakan publik (Prakoso, 2017). Dalam paper ini untuk melakukan analisis terhadap anggaran belanja pemerintah daerah berdasarkan metode spending review berbasis performance based budgeting (PBB) sebagai berikut:

\section{Review Alokasi}

Review alokasi dilakukan dengan melihat keseluruhan dari alokasi anggaran dan realisasi belanja daerah yang meliputi belanja operasional, belanja modal dan belanja lainlain. Adapun gambaran mengenai alokasi belanja daerah di Kabupaten Sleman pada tahun 2017 dan tahun 2018 seperti pada gambar berikut:

\section{Gambar 3. Realisasi Anggaran Belanja Daerah Kabupaten Sleman Tahun 2017 Dan 2018}

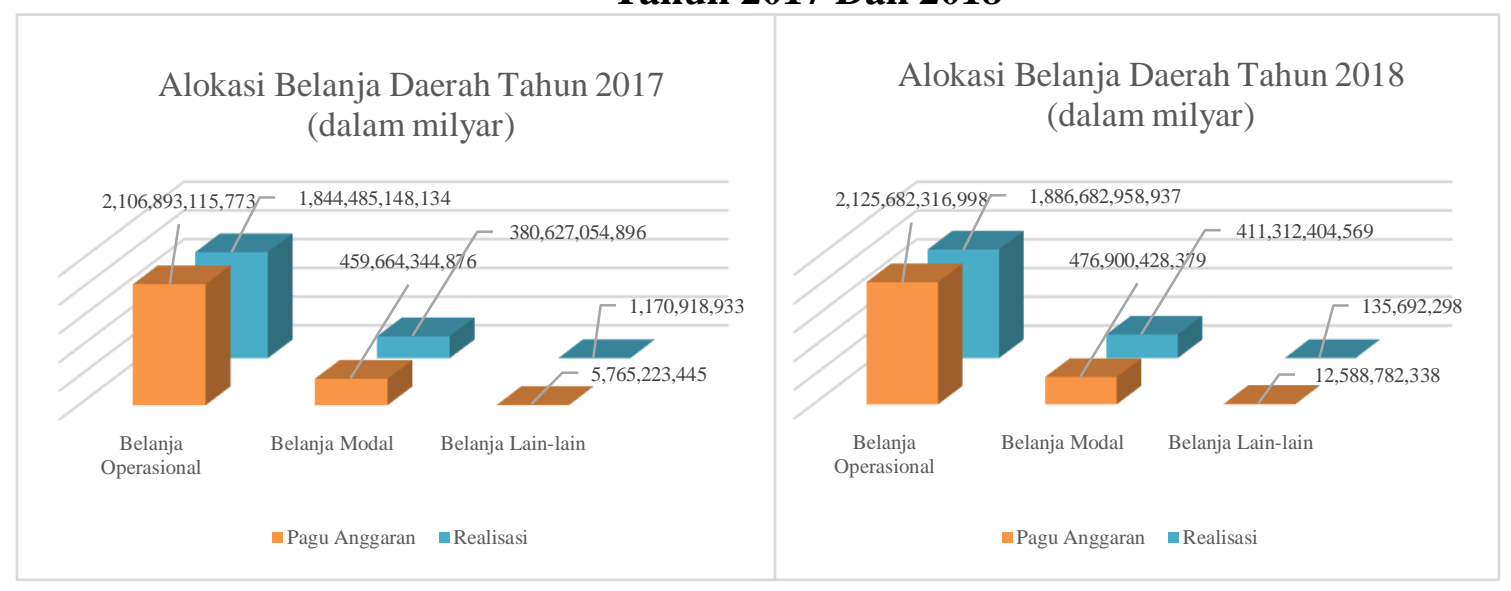

Sumber: Realisasi Anggaran Belanja Daerah Kab.Sleman Tahun 2017-2018

Dari gambar 2. dapat dijelaskan Pemerintah Kabupaten Sleman untuk tahun anggaran 2017, alokasi belanja operasional daerah dengan pagu anggaran 2.106 milyar rupiah dapat 
terealisasikan sebesar 1.844 milyar rupiah atau penyerapan anggaran mencapai $(87,55 \%)$ sehingga masih ada 262,4 milyar rupiah anggaran belanja operasional yang belum terserap. Kemudian dalam tahun anggaran yang sama (2017), alokasi untuk belanja modal dengan pagu anggaran 459,6 milyar rupiah terserap 380,6 milyar rupiah dimana prosentase penyerapan anggarannya mencapai $(82,81 \%)$ dan sisa anggaran yang belum terealisasi sebesar 79,03 milyar rupiah. Sedangkan masih dalam tahun anggaran 2017, alokasi belanja lain-lain dengan pagu anggaran sebesar 5,76 milyar rupiah untuk realisasi anggarannya mencapai 1,17 milyar rupiah atau tingkat penyerapannya hanya sebesar (20,31\%) dan masih ada anggaran yang belum terserap mencapai angka sekitar 4,59 milyar rupiah. Sehingga pagu anggaran belanja tahun 2017 secara keseluruhan yang mencapai 2.572 milyar rupiah total terealisasi sebesar 2.226 milyar rupiah atau penyerapan anggaran belanja mencapai $(86,55 \%)$ sehingga ada sekitar 346 milyar rupiah anggaran belum terserap yang bisa menjadi potensi untuk penghematan anggaran di tahun 2017. Total indikasi inefisiensi belanja pemerintah Kabupaten Sleman berdasarkan review alokasi belanja daerah tahun 2017 mencapai 346 milyar rupiah atau (13,23\%) dari anggaran belanja pada APBD Kabupaten Sleman tahun 2017 sebesar 2.615 milyar rupiah.

Kemudian pada tahun anggaran 2018, pagu anggaran untuk alokasi belanja operasional Kabupaten Sleman sebesar 2.215 milyar rupiah dengan realisasi sebesar 1.886 milyar rupiah atau tingkat penyerapan anggaran $(88,76 \%)$ dan masih ada 238,9 milyar rupiah yang belum teralisasi, sedangkan untuk alokasi belanja modal dengan pagu anggaran sebesar 476,9 milyar dapat direalisasikan sebesar 411,3 milyar rupiah dengan tingkat penyerapan anggaran mencapai $(86,25 \%)$ sehingga masih terdapat anggaran sebesar 65,5 milyar rupiah yang belum terealisasikan. Dalam tahun anggaran yang sama (2018), untuk alokasi belanja lain-lain dengan pagu anggaran sebesar 12,5 milyar rupiah hanya dapat direalisasikan sebesar 135 juta rupiah atau tingkat penyerapannya hanya sebesar $(1,08 \%)$ sehingga masih ada anggaran yang belum terserap yang mencapai 12,4 milyar rupiah. Pada tahun 2018 dengan pagu anggaran belanja daerah secara keseluruhan mencapai 2.615 milyar yang dapat direalisasikan mencapai angka sebesar 2.298 milyar rupiah atau tingkat penyerapan anggara belanja daerah di Kabupaten Sleman pada tahun tersebut mencapai (87,88\%) sehingga masih ada sekitar 317 milyar rupiah anggaran belum terserap dan dapat menjadi potensi penghematan anggaran di tahun 2018. Total indikasi inefisiensi belanja pemerintah Kabupaten Sleman berdasarkan review alokasi belanja daerah tahun 2018 mencapai 317 milyar rupiah atau (12,1\%) dari anggaran belanja pada APBD Kabupaten Sleman tahun 2018 sebesar 2.627 milyar rupiah.

Berdasarkan review alokasi yang dilakukan terhadap realisasi anggaran belanja daerah Kabupaten Sleman pada tahun 2017 dan 2018 dapat diketahui penghematan anggaran belanja tahun 2017 sebesar 346 milyar rupiah, tahun 2018 sebesar 317 milyar rupiah. Dalam periode dua tahun anggaran tersebut dapat diartikan untuk rata-rata penghematan anggaran di Kabupaten Sleman dilihat dari aspek review alokasi adalah sebesar 331,5 milyar rupiah.

\section{Review Tolak Ukur Dan Kinerja}

Review pada anggaran pengeluaran dengan mengelompokkan unit-unit sejenis sehingga dapat diketahui kinerja terbaik dari unit tersebut dalam satu kelompok unit yang sama, 
ISSN 2088-7469 (Paper) ISSN 2407-6864 (Online)

Volume 10 Nomor 2 (2020)

mengukur selisih antara kinerja suatu unit dengan kinerja terbaik sebagai inefisiensi atau sering dikenal dengan istilah metode benchmarking (Parhusip, 2016). Pengelompokkan unitunit sejenis ini dilakukan salah satunya untuk menjaga kualitas belanja anggaran, yakni pada belanja Pendidikan dan kesehatan sebagai upaya investasi untuk pengembangan SDM. Spending review pada pengelolaan anggaran dapat memberikan manfaat secara menyeluruh, tetapi belum ditemukan seberapa besar pengaruh spending review terhadap perbaikan kualitas output ataupun pelayanan (Parhusip, 2016). Terdapatnya peningkatan pelayanan atau output dapat dikaji dari LAKIP masing-masing organisasi (Parhusip, 2016). Untuk spending review pada aspek tolak ukur dan kinerja dilihat dari belanja untuk pelayanan dasar kepada masyarakat bidang Pendidikan dan kesehatan di Kabupaten Sleman sebagai berikut:

Tabel 3. Belanja Anggaran Pelayanan Kesehatan Dan Pendidikan Kabupaten Sleman Tahun 2017

\begin{tabular}{|l|c|c|c|}
\hline \multicolumn{1}{|c|}{ Sasaran } & Anggaran & Realisasi Anggaran & Capaian Kinerja (\%) \\
\hline $\begin{array}{l}\text { Meningkatkan Kualitas } \\
\text { Kesehatan Masyarakat }\end{array}$ & 321.178 .965 .610 & 294.823 .516 .634 & 100,11 \\
\hline $\begin{array}{l}\text { Meningkatnya kualitas } \\
\text { Pendidikan dan akses } \\
\text { pendidikan }\end{array}$ & 174.621 .028 .606 & 116.672 .971 .579 & 103,49 \\
\hline
\end{tabular}

Sumber: LKJIP Kab.Sleman, 2017

Dari tabel tersebut untuk tahun anggaran 2017, pada belanja yang dilakukan pemerintah Kabupaten Sleman untuk pembangunan sumber daya manusia dari aspek belanja untuk pelayanan kesehatan masyarakat dengan anggaran sebesar 321 milyar rupiah dapat direalisasikan 294 milyar rupiah (91,79\%) dengan capaian kinerja mencapai 100,11\%. Sedangkan untuk belanja dalam meningkatkan pelayanan Pendidikan sebesar 174 milyar rupiah dapat terealisasi 116 milyar rupiah (66,81\%) dengan capaian kinerja mencapai $(103,49 \%)$. Secara umum dalam upaya untuk pembangunan sumber daya manusia pada belanja pelayanan kesehatan memiliki penyerapan anggaran lebih tinggi dari pada aspek layanan Pendidikan, sebaliknya untuk capaian kinerja lebih tinggi dalam aspek layanan Pendidikan daripada pelayanan kesehatan. Sedangkan untuk belanja anggaran pada pembangunan sumber daya manusia tahun 2018 dapat dilihat pada tabel berikut:

Tabel 4. Belanja Anggaran Pelayanan Kesehatan Dan Pendidikan Kabupaten Sleman Tahun 2018

\begin{tabular}{|l|c|c|c|}
\hline \multicolumn{1}{|c|}{ Sasaran } & Anggaran & Realisasi Anggaran & Capaian Kinerja (\%) \\
\hline $\begin{array}{l}\text { Meningkatkan Kualitas } \\
\text { Kesehatan Masyarakat }\end{array}$ & 312.946 .454 .310 & 282.726 .109 .697 & 102,21 \\
\hline $\begin{array}{l}\text { Meningkatnya kualitas } \\
\text { Pendidikan dan akses } \\
\text { pendidikan }\end{array}$ & 201.476 .289 .822 & 184.074 .042 .351 & 103,33 \\
\hline
\end{tabular}

Sumber: LKJIP Kab.Sleman, 2018

Dari tabel tersebut untuk tahun anggaran 2018, belanja pemerintah Kabupaten Sleman untuk pembangunan sumber daya manusia dari aspek belanja untuk pelayanan kesehatan masyarakat sebesar 312 milyar rupiah dapat direalisasikan 282 milyar rupiah (90,34\%) 
dengan capaian kinerja mencapai 102,21\%. Sedangkan untuk belanja dalam meningkatkan pelayanan Pendidikan dengan anggaran sebesar 201 milyar rupiah dapat terealisasi 184 milyar rupiah $(91,36 \%)$ dengan capaian kinerja mencapai $(103,33 \%)$. Secara umum untuk prosentase penyerapan anggaran belanja dalam meningkatkan pelayanan kesehatan dan Pendidikan hampir sama yakni mencapai 90\% lebih, akan tetapi untuk capaian kinerja pada tahun 2018 lebih tinggi pada aspek pelayanan Pendidikan daripada layanan kesehatan masyarakat. Adapun rata-rata realisasi belanja anggaran untuk pembangunan manusia dari bidang layanan kesehatan dan Pendidikan dapat dilihat pada grafik gambar sebagai berikut:

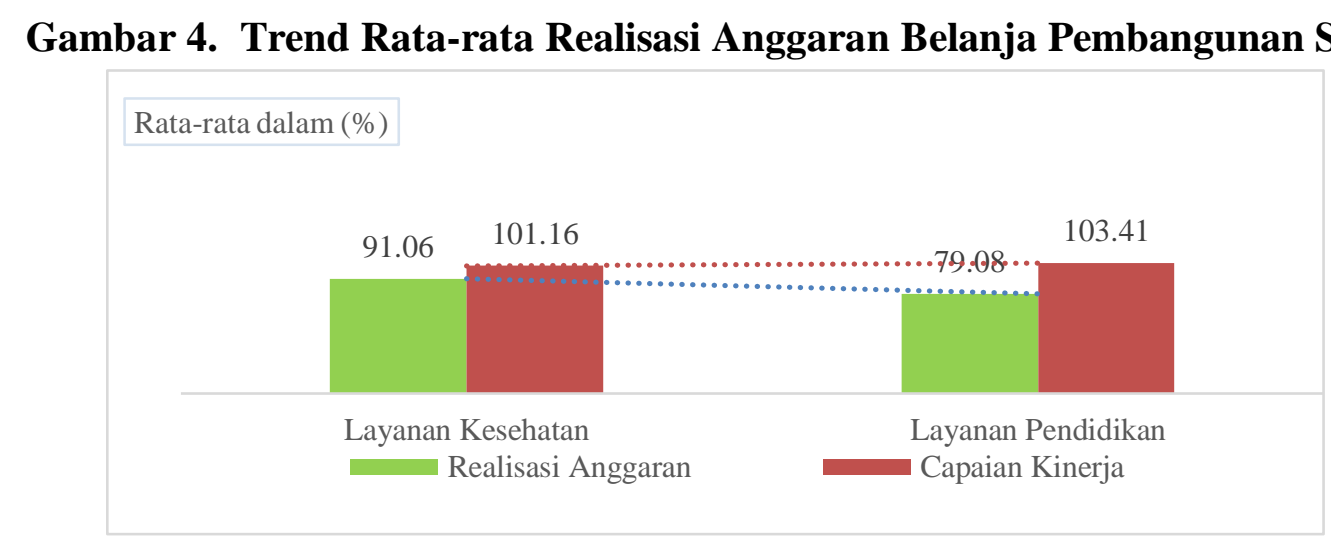

Sumber: Olahan Data Primer, 2019

Gambar 4 di atas menunjukan rata-rata realisasi penggunaan anggaran belanja untuk pembangunan manusia (SDM) dari 2017-2018 di Kabupaten Sleman, dengan rata-rata realisasi anggaran dalam layanan kesehatan sebesar 91,06\% dapat memenuhi capaian kinerja di bidang kesehatan sebesar 101,16\%. Kemudian untuk bidang layanan Pendidikan dengan rata-rata realisasi anggaran sebesar 79,08\% menghasilkan capaian kinerja di bidang tersebut sebesar $103,41 \%$. Dari realisasi penggunaan anggaran belanja untuk bidang pembangunan SDM tersebut maka hasilnya dapat dilihat dari terjadinya peningkatan angka indeks pembangunan manusia dari 82,85\% pada tahun 2017 menjadi 83,42\% di tahun 2018, dimana nilai indeks tersebut berada di atas angka 80 dengan kategori sangat tinggi (IPM $\geq 80$ ) (BPS Kab.Sleman, 2019). Adapun untuk nilai indek pembangunan manusia di Kabupaten Sleman tahun 2017-2018 seperti pada gambar berikut:

\section{Gambar 5. Perbandingan Target Dan Capaian Indeks Pembangunan Manusia 2017-2018 Kabupaten Sleman}

Capaian Indek Pembangunan Manusia 2017-2018 Di Kab.Sleman (Dalam \%)

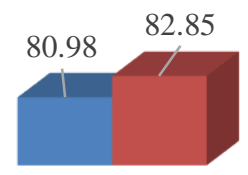

Tahun 2017

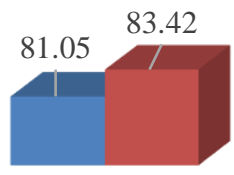

Tahun 2018
- Target

- Capaian

Sumber: LKJIP Kab.Sleman, 2017-2018 
Dari gambar tersebut dapat dilihat untuk hasil dari capaian indek pembangunan manusia di Kabupaten Sleman tahun 2017 dengan target 80,98\% dapat tercapai dengan capaian target sebesar 82,85\%. Tahun 2018 dengan target kinerja yang lebih rendah pada bidang pembangunan manusia yakni $81,05 \%$ dapat tercapai dengan capaian target sebesar $83,42 \%$. Secara umum penggunaan anggaran belanja daerah untuk memenuhi pelayanan dasar masyarakat yakni melalui pembangunan sumber daya manusia pada bidang layanan kesehatan dan Pendidikan tahun 2017 dan 2018 terdapat adanya peningkatan tetapi tidak terlalu signifikan dari nilai indeks pembangunan manusia sebesar $0,57 \%$.

\section{Analisis Deviasi Kebutuhan}

Dilakukan dengan analisis terhadap deviasi kebutuhan dengan menghitung deviasi antara realisasi belanja operasional dengan rata-rata realisasi belanja operasional dalam satu tahun anggaran (Parhusip, 2016). Dengan kata lain yakni mengukur kebutuhan riil belanja operasional sesuai kebutuhan dan mengidentifikasi potensi savingnya. Untuk belanja operasional dalam belanja daerah dialokasikan untuk kebutuhan belanja pegawai, belanja barjas (barang-jasa), bunga, hibah dan bantuan sosial (bansos). Adapun besaran dari masingmasing alokasi untuk belanja tersebut dapat dilihat seperti pada gambar sebagai berikut:

\section{Gambar 6. Realisasi Belanja Operasional Pemerintah Kabupaten Sleman} Tahun 2017 Dan 2018

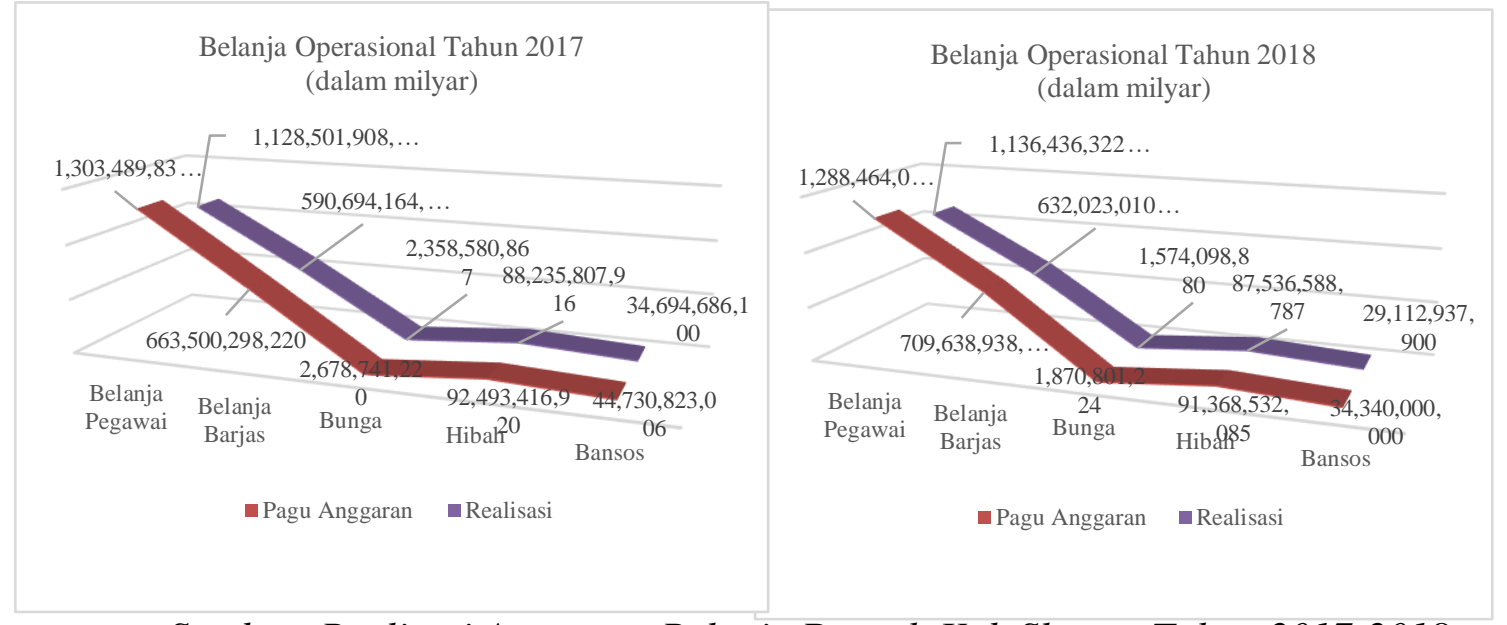

Sumber: Realisasi Anggaran Belanja Daerah Kab.Sleman Tahun 2017-2018

Dari gambar tersebut dapat diketahui untuk belanja operasional dari Pemerintah Kabupaten Sleman tahun 2017 pagu anggaran secara keseluruhan mencapai 2.106 milyar rupiah dan total realisasi sebesar 1.844 milyar rupiah dengan prosentase realisasi anggaran mencapai $(87,55 \%)$. Dengan total realisasi anggaran tersebut dapat diketahui untuk rata-rata realisasi belanja operasional pada tahun 2017 mencapai 153 milyar dalam satu tahun anggaran. Untuk kebutuhan belanja pegawai dengan pagu anggaran 1.303 milyar rupiah dan realisasi anggarannya sebesar 1.128 milyar rupiah terdapat potensi saving 174,9 milyar rupiah, kemudian untuk kebutuhan belanja barjas dengan pagu anggaran 663,5 milyar rupiah dengan realisasi anggaran mencapai 590,6 milyar maka terdapat potensi saving 72,8 milyar 
rupiah. Pada kebutuhan belanja bunga dengan pagu anggaran sebesar 2,6 milyar rupiah dan realisasi anggaran mencapai 2,3 milyar rupiah maka potensi saving 320 juta rupiah, sedangkan untuk kebutuhan belanja hibah dengan pagu anggaran sebesar 92,4 milyar rupiah dan realisasi anggaran sebesar 88,2 milyar rupiah maka terdapat potensi saving anggaran mencapai 4,2 milyar rupiah. Untuk kebutuhan belanja bantuan sosial dengan pagu anggaran 44,7 milyar dan realisasinya yang mencapai 34,6 milyar rupiah maka terdapat potensi saving sebesar 10,03 milyar rupiah. Sehingga hasil analisis deviasi pada tahun 2017 untuk kebutuhan pada belanja operasional dengan realisasi anggaran mencapai 1.844 milyar rupiah dari total pagu anggaran belanja operasional mencapai 2.106 milyar rupiah terdapat potensi saving anggaran belanja sebesar 262,4 milyar rupiah atau deviasi antara kebutuhan dengan alokasi anggaran belanja operasional daerah tahun 2017 di Kabupaten Sleman sebesar (12,46\%).

Sedangkan pada tahun 2018 untuk belanja operasional Pemerintah Kabupaten Sleman dengan pagu anggaran secara keseluruhan mencapai 2.125 milyar rupiah dan total realisasi anggaran belanja mencapai 1.886 milyar rupiah. Dari total realisasi anggaran tersebut dapat diketahui untuk rata-rata realisasi belanja operasional pada tahun 2018 mencapai 157,2 milyar dalam satu tahun anggaran. Dalam kebutuhan belanja pegawai dengan pagu anggaran 1.288 milyar rupiah dan realisasi anggarannya sebesar 1.136 milyar rupiah terdapat potensi saving 152 milyar rupiah. Untuk kebutuhan belanja barjas dengan pagu anggaran 709,6 milyar rupiah dengan realisasi anggaran mencapai 632 milyar maka terdapat potensi saving 77,6 milyar rupiah, sedangkan pada kebutuhan belanja bunga dengan pagu anggaran sebesar 1,8 milyar rupiah dan realisasi anggaran mencapai 1,5 milyar rupiah maka terdapat potensi saving 296 juta rupiah. Untuk kebutuhan belanja hibah dengan pagu anggaran sebesar 91,3 milyar rupiah dan realisasi anggaran sebesar 87,5 milyar rupiah maka terdapat potensi saving anggaran yang mencapai 3,8 milyar rupiah. Kemudian pada kebutuhan belanja bantuan sosial dengan pagu anggaran 34,3 milyar dan realisasinya yang mencapai 29,1 milyar rupiah maka terdapat potensi saving sebesar 5,2 milyar rupiah. Hasil analisis deviasi pada tahun 2018 untuk kebutuhan pada belanja operasional dengan realisasi anggaran yang mencapai 1.886 milyar rupiah dari total pagu anggaran belanja operasional sebesar 2.125 milyar rupiah maka terdapat potensi saving anggaran belanja sebesar 238,9 milyar rupiah atau deviasi antara kebutuhan dengan alokasi anggaran belanja operasional daerah tahun 2018 di Kabupaten Sleman sebesar $(11,24 \%)$.

Hasil analisis deviasi kebutuhan terhadap alokasi kebutuhan pada belanja operasional Pemerintah Kabupaten Sleman tahun anggaran 2017 dan 2018, dimana pada tahun 2017 deviasi antara kebutuhan dengan alokasi belanja operasional daerah mencapai $(12,46 \%)$ atau sekitar 262,4 milyar rupiah. Kemudian pada 2018 deviasi antara kebutuhan dengan alokasi anggaran belanja operasional daerah mencapai $(11,24 \%)$ atau sebesar 238,9 milyar rupiah. Sehingga dapat diartikan dalam dua tahun anggaran yakni 2017 dan 2018 Pemerintah Kabupaten Sleman memiliki tingkat rata-rata deviasi kebutuhan dengan alokasi anggaran belanja daerah sebesar $(11,85 \%)$ atau sebesar 250,65 milyar rupiah. 
ISSN 2088-7469 (Paper) ISSN 2407-6864 (Online)

Volume 10 Nomor 2 (2020)

\section{Performance Based Budgeting (PBB) Layanan Pendidikan Dan Kesehatan}

Anggaran berbasis kinerja merupakan anggaran yang memiliki keterkaitan antara pengeluaran negara dengan hasil yang diharapkan (output dan outcome) (Kurrohman, 2013). Menurut Kong (2005), ada tiga jenis orientasi pengukuran kinerja di dalam penganggaran (Prakoso, 2017), yakni dilihat sebagai berikut:

\section{a. Berfokus Pada Sumber Daya}

Yakni anggaran pemerintah memiliki tujuan untuk mengukur kinerja sumber daya input seperti keuangan atau sumber daya lainnya. Untuk sumber dana dalam penyelenggaraan pelayanan dasar melalui bidang kesehatan dan Pendidikan di Kabupaten Sleman. Untuk bidang layanan kesehatan dari pagu anggaran sebesar Rp 321.178.965.610,00 dapat terealisasi sebesar Rp 294.823.516.634,00 (91,79\%) tahun 2017, sedangkan pada tahun anggaran 2018 dari pagu anggaran sebesar Rp 312.946.454.310,00 dapat terealisasi sebesar Rp 282.726.109.697,00 atau mencapai (90,34\%). Untuk bidang pendidikan dengan pagu anggaran sebesar Rp 174.621.028.606,00 dapat terealisasi sebesar Rp 116.672.971.579 atau realisasi mencapai $(66,81 \%)$ tahun 2017, dan tahun 2018 dengan pagu anggaran sebesar Rp201.476.289.822 dapat direalisasikan sebesar Rp 184.074.042.351 atau mencapai $(91,36 \%)$.

Untuk realisasi anggaran dalam layanan kesehatan mengalami penurunan sebesar $(1,45 \%)$, sebaliknya untuk bidang Pendidikan realisasi anggarannya mengalami kenaikan cukup signifikan yakni sebesar (24,55\%). Sehingga dalam dua tahun anggaran (2017 dan 2018) untuk rata-rata penggunaan anggaran belanja pada layanan kesehatan mencapai $(91,06 \%)$ atau sebesar Rp 288.774.813.165,5. Kemudian untuk bidang layanan Pendidikan rata-rata penggunaan anggaran belanja mencapai $(79,08 \%)$ atau mencapai $\mathrm{Rp}$ 150.373.506.965.

\section{b. Berfokus Pada Organisasi}

Dimana anggaran pemerintah juga fokus pada kinerja proses dan hasil organisasi, termasuk keuangan, layanan dan program dan / atau kegiatan. Adapun untuk layanan program dan kegiatan bidang kesehatan beserta realisasinya dapat dilihat pada rincian tabel berikut: 
ISSN 2088-7469 (Paper) ISSN 2407-6864 (Online)

Volume 10 Nomor 2 (2020)

Tabel 4. Layanan Program Dan Kegiatan Bidang Kesehatan

\begin{tabular}{|c|c|c|c|}
\hline No & Program & Anggaran & Realisasi \\
\hline 1 & $\begin{array}{l}\text { Program obat dan perbekalan } \\
\text { kesehatan }\end{array}$ & 7.353.224.000 & 7.031 .485 .946 \\
\hline 2 & Program upaya kesehatan masyarakat & 76.172 .911 .603 & 63.375 .032 .054 \\
\hline 3 & $\begin{array}{l}\text { Program pengawasan obat dan } \\
\text { makanan }\end{array}$ & 598.581 .500 & 526.582 .200 \\
\hline 4 & $\begin{array}{l}\text { Program promosi kesehatan dan } \\
\text { pemberdayaan masyarakat }\end{array}$ & 1.408 .690 .600 & 1.225 .188 .300 \\
\hline 5 & Program perbaikan gizi masyarakat & 620.584 .000 & 611.933 .000 \\
\hline 6 & $\begin{array}{l}\text { Program pengembangan lingkungan } \\
\text { sehat }\end{array}$ & 220.115 .000 & 212.179 .000 \\
\hline 7 & $\begin{array}{l}\text { Program pencegahan dan } \\
\text { penanggulangan penyakit menular }\end{array}$ & 2.468 .022 .800 & 1.930 .515 .103 \\
\hline 8 & $\begin{array}{l}\text { Program pencegahan dan pengendalian } \\
\text { penyakit tidak menular \& kesehatan jiwa }\end{array}$ & 438.488 .300 & 424.539 .800 \\
\hline 9 & $\begin{array}{l}\text { Program standarisasi pelayanan } \\
\text { kesehatan }\end{array}$ & 1.752 .480 .000 & 1.382 .338 .239 \\
\hline 10 & $\begin{array}{l}\text { Program pengadaan, peningkatan } \\
\text { sarana dan prasarana rumah } \\
\text { sakit/rumah sakit jiwa/rumah sakit paru- } \\
\text { paru/rumah sakit mata }\end{array}$ & 39.728 .088 .032 & 39.246 .204 .342 \\
\hline 11 & $\begin{array}{l}\text { Program peningkatan pelayanan } \\
\text { kesehatan anak balita }\end{array}$ & 94.911 .500 & 87.629 .000 \\
\hline 12 & $\begin{array}{l}\text { Program pengawasan dan } \\
\text { pengendalian kesehatan makanan }\end{array}$ & 26.459 .000 & 25.738 .000 \\
\hline 13 & $\begin{array}{l}\text { Program peningkatan pelayanan } \\
\text { kesehatan }\end{array}$ & 164.938 .785 .188 & 152.349 .525 .022 \\
\hline 14 & Program perencanaan ocial budaya & 403.699 .500 & 393.285 .950 \\
\hline 15 & Program keluarga berencana & 6.240 .461 .900 & 5.692 .960 .395 \\
\hline 16 & Program kesehatan reproduksi remaja & 75.000 .000 & 75.000 .000 \\
\hline 17 & Program pelayanan kontrasepsi & 80.000 .000 & 75.972 .536 \\
\hline 18 & $\begin{array}{l}\text { Program pembinaan peran serta } \\
\text { masyarakat dalam pelayanan KB/KR } \\
\text { yang mandiri }\end{array}$ & 1.007 .348 .400 & 1.002 .797 .535 \\
\hline 19 & $\begin{array}{l}\text { Program pengembangan pusat } \\
\text { pelayanan informasi dan konseling KRR }\end{array}$ & 316.593 .900 & 314.273 .900 \\
\hline 20 & $\begin{array}{l}\text { Program penyiapan tenaga pendamping } \\
\text { kelompok bina keluarga }\end{array}$ & 339.372 .400 & 337.386 .395 \\
\hline 21 & $\begin{array}{l}\text { Program pengembangan model } \\
\text { operasional BKB-Posyandu-PADU }\end{array}$ & 75.234 .400 & 75.234 .400 \\
\hline 22 & $\begin{array}{l}\text { Program pembinaan dan } \\
\text { pemasyarakatan olah raga }\end{array}$ & 6.282 .266 .662 & 4.265 .418 .930 \\
\hline 23 & $\begin{array}{l}\text { Program peningkatan sarana dan } \\
\text { prasarana olahraga }\end{array}$ & 2.200 .000 .000 & 1.960 .054 .050 \\
\hline 24 & $\begin{array}{l}\text { Program peningkatan penanggulangan } \\
\text { Narkoba, PMS, termasuk HIVIAIDS }\end{array}$ & 105.135 .625 & 104.835 .600 \\
\hline
\end{tabular}

Sumber: Dinas Kesehatan Kab.Sleman, 2018

Kemudian untuk program-program layanan Pendidikan realisasi anggaran program dapat dirinci dalam tabel berikut:

Tabel 5. Realisasi Anggaran Program Layanan Pendidikan

\begin{tabular}{|c|l|c|c|}
\hline No & \multicolumn{1}{|c|}{ Program } & Anggaran 2018 & Realisasi 2018 \\
\hline 1 & $\begin{array}{l}\text { Program Wajib Belajar Pendidikan Dasar Sembilan } \\
\text { Tahun }\end{array}$ & $144.173 .228 .621,80$ & 137.013 .665 .093 \\
\hline 2 & $\begin{array}{l}\text { Program Peningkatan Kualitas Pendidikan Non } \\
\text { Formal }\end{array}$ & $1.348 .070 .300,00$ & $1.273 .426 .650,00$ \\
\hline 3 & $\begin{array}{l}\text { Program Peningkatan Mutu Pendidik dan Tenaga } \\
\text { Kependidikan }\end{array}$ & $35.833 .249 .300,00$ & $27.215 .090 .674,00$ \\
\hline 4 & Program Manajemen Pelayanan Pendidikan & $7.245 .468 .600,00$ & $6.186 .422 .154,00$ \\
\hline 5 & $\begin{array}{l}\text { Program Pengembangan Kreativitas Siswa dan } \\
\text { Guru }\end{array}$ & $1.844 .133 .500,00$ & $1.625 .041 .350,00$ \\
\hline 6 & Program Pengembangan Budaya Baca & $1.564 .995 .000,00$ & $1.551 .465 .370,00$ \\
\hline 7 & $\begin{array}{l}\text { Program Pengembangan dan Pembinaan } \\
\text { Perpustakaan }\end{array}$ & $1.359 .440 .850,00$ & $1.335 .970 .580,00$ \\
\hline 8 & Program Pendidikan Anak Usia Dini & $7.409 .396 .550,00$ & $7.198 .512 .180,00$ \\
\hline 9 & $\begin{array}{l}\text { Program Upaya Pencegahan Penyalahgunaan } \\
\text { Narkoba }\end{array}$ & $698.307 .100,00$ & $674.448 .300,00$ \\
\hline
\end{tabular}

Sumber: Dinas Pendidikan Kabupaten Sleman, 2018 
ISSN 2088-7469 (Paper) ISSN 2407-6864 (Online)

Volume 10 Nomor 2 (2020)

\section{c. Berfokus pada pelanggan}

Yakni anggaran pemerintah memberikan tekanan pada langkah kinerja (kepuasan, kualitas layanan dan hasil). Untuk kepuasan terhadap pelayanan dasar yakni pada bidang kesehatan dan Pendidikan dapat dilihat seperti pada gambar berikut:

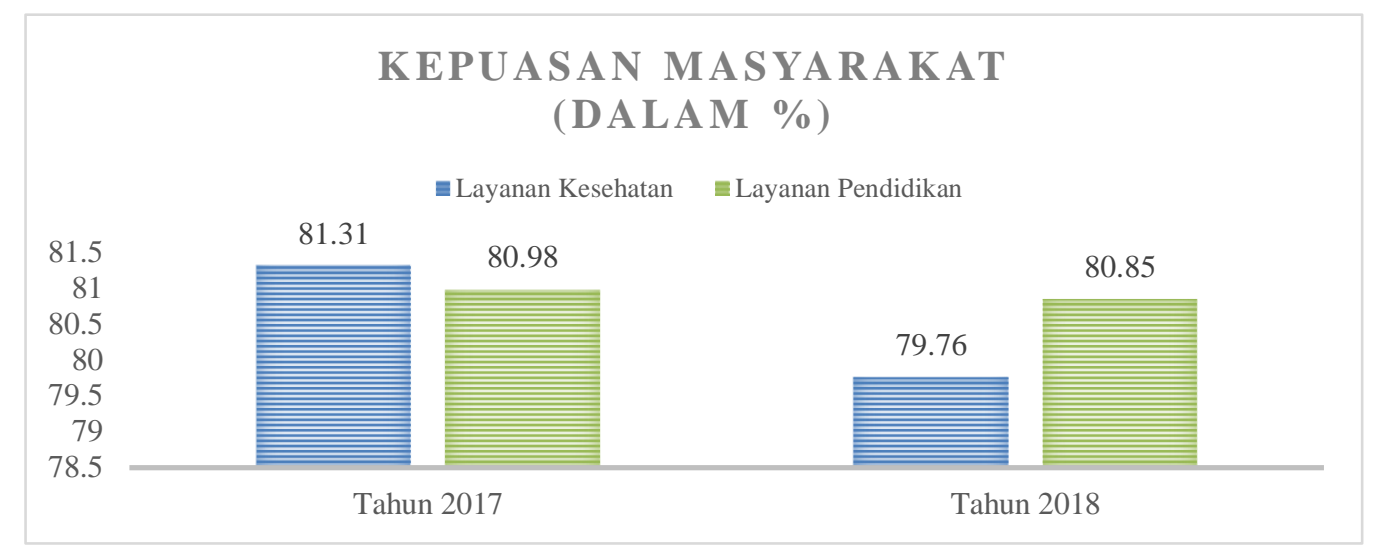

Sumber: LKJIP Kabupaten Sleman, 2017 \& 2018

Dari gambar tersebut diketahui untuk kepuasan masyarakat Kabupaten Sleman terhadap layanan kesehatan tahun 2017 adalah sebesar 81,31\% mengalami penurunan tahun 2018 menjadi 79,76\%. Kemudian untuk kepuasan terhadap layanan Pendidikan juga mengalami sedikit penurunan dari 80,98\% tahun 2017 menjadi 80,85\% pada tahun 2018. Dapat dikatakan selama dua tahun dari 2017 dan 2018 untuk kepuasan masyarakat terhadap pelayanan kesehatan memiliki rata-rata sebesar $80,53 \%$ sedangkan untuk kepuasan masyarakat terhadap pelayanan di bidang Pendidikan memiliki rata-rata sebesar $80,91 \%$ dimana nilai kepuasan masyarakat diatas $80 \%$ sehingga masuk dalam kategori baik (B).

Kemudian dengan realisasi anggaran belanja tahun 2017 untuk pelayanan kesehatan sebesar $91,79 \%$ dengan capaian kinerja sasaran sebesar $100,11 \%$ dapat dihasilkan kualitas kesehatan masyarakat yakni untuk angka kematian ibu melahirkan di Sleman terjadi penurunan sebesar $14,2 \%$ dari target sebesar $62,79 \%$ realisisai $42,4 \%$, atau mencapai $132,82 \%$, angka kematian bayi lebih baik karena lebih kecil dari target 4,33\%, terealisasi $4,21 \%$ atau mencapai $102,85 \%$, angka kematian anak balita per 1.000 kelahiran lebih baik dari target $<1.8 \%$ hanya terjadi $0,14 \%$. Realisasi tahun 2016 sebesar $0,35 \%$ sehingga mengalami penurunan dan status gizi buruk lebih baik karena menurun dari $0,46 \%$ menjadi $0,44 \%$. Sedangkan pada tahun 2018 untuk realisasi belanja pada bidang Pendidikan mencapai 90,34\% dengan capaian kinerja sasaran sebesar $102,21 \%$ hasil dari pelayanan kesehatan tersebut yakni untuk angka kematian ibu melahirkan menurun sebesar 23,48\% dari target sebesar 55,42\% realisasi 50,44\%, atau mencapai $108,99 \%$. Selanjutnya angka kematian bayi lebih baik karena lebih kecil dari target $4,23 \%$, terealisasi $4,11 \%$ atau mencapai $102,84 \%$, dan angka kematian anak balita per 1.000 kelahiran lebih baik dari target $<1.7 \%$ hanya terjadi $0,22 \%$.

Untuk hasil penyelenggaraan dari layanan Pendidikan pada 2017 dengan realisasi anggaran sebesar $66,81 \%$ dan capaian kinerja sasaran sebesar 103,49\% maka dihasilkan 
untuk penyediaan sekolah baik pemerintah maupun pihak swasta dengan sarana prasarana sesuai standar pelayanan minimal (SPM) dimana untuk SD/MI berjumlah 534 sekolah, terdiri 379 sekolah negeri dan 155 sekolah swasta, dengan jumlah bangunan 3.828 unit, dalam kondisi baik 3.317 unit (86,65\%) kondisi rusak ringan 450 Unit $(11,76 \%)$, dan kondisi rusak berat 61 (1,59\%). Kemudian untuk SD/MI berjumlah 534 sekolah, terdiri 379 sekolah negeri dan 155 sekolah swasta, dengan jumlah bangunan 3.828 unit, dalam kondisi baik 3.317 unit $(86,65 \%)$ kondisi rusak ringan 450 Unit $(11,76 \%)$, dan kondisi rusak berat 61 (1,59\%). Untuk SMP/MTs berjumlah 137 sekolah, terdiri 65 sekolah negeri dan 72 sekolah swasta dengan jumlah bangunan 1.544 unit, dalam kondisi baik 1.440 unit $(93,26 \%)$ kondisi rusak ringan 76 Unit $(4,92 \%)$, dan kondisi rusak berat $28(1,81 \%)$. Ditambah dengan adanya penyediaan anggaran jaminan pembiayaan pendidikan daerah (JPPD) untuk siswa keluarga miskin pada jenjang SMA dan SMK terealisasi sebesar Rp 20.877.750.000 untuk 19.879 siswa.

Kemudian untuk tahun 2018 dengan realisasi anggaran belanja Pendidikan sebesar sebesar 91,36\% dan capaian kinerja sasaran sebesar 91,81\% dihasilkan penyediaan sekolah oleh pemerintah maupun pihak swasta dengan sarana prasarana sesuai standar pelayanan minimal (SPM) yakni SD/MI berjumlah 545 sekolah, terdiri 376 sekolah negeri dan 169 sekolah swasta, dengan jumlah bangunan 3.998 unit, dalam kondisi baik 3.525 unit $(88,17 \%)$ 394 Unit $(9,85 \%)$, dan kondisi rusak berat 79 (1,98\%). Jumlah sekolah SD/MI pada tahun ini meningkat $0,92 \%$ dibanding tahun sebelumnya dengan jumlah kondisi rusak berat menurun $0,8 \%$ dibanding tahun 2017 sebesar 2,78\%. Untuk SMP/MTs berjumlah 145 sekolah, terdiri 64 sekolah negeri dan 81 sekolah swasta, dengan jumlah bangunan 1.580 unit, dalam kondisi baik 1.453 unit (91,96\%) kondisi rusak ringan 99 Unit $(6,27 \%)$, dan kondisi rusak berat $28(1,77 \%)$. Jumlah sekolah SMP/MTs pada tahun 2018 meningkat 3,57\% dibanding tahun sebelumnya dengan jumlah kondisi baik meningkat $1,98 \%$ dibanding tahun sebelumnya sebesar 89,98\%. Untuk Tahun 2018 dalam penyediaan anggaran jaminan pembiayaan pendidikan daerah (JPPD) untuk siswa keluarga miskin pada jenjang SMA dan SMK terealisasi sebesar Rp 8.947.250.000 untuk 9.499 siswa.

\section{PENUTUP}

Berdasarkan hasil dan pembahasan pada penelitian tersebut, maka dapat diambil beberapak kesimpulan sebagai berikut:

1. Secara umum kondisi anggaran belanja daerah Pemerintah Kabupaten Sleman Tahun 2017 dan 2018 mengalami kenaikan sebesar (0,45\%) atau 12 milyar rupiah dari 2.615 milyar menjadi 2.627 milyar rupiah, dimana alokasi untuk belanja daerah mayoritas digunanakan dalam memenuhi kebutuhan belanja pegawai dengan rata-rata 1.257 milyar rupiah atau 47,96\% dari total rata-rata anggaran belanja daerah tahun 2017 dan 2018.

2. Anggaran belanja pegawai Pemerintah Kabupaten Sleman mengalami penurunan dari 1.257,6 milyar pada 2017 menjadi 1.256,5 milyar tahun 2018 sehingga menciptakan efisiensi anggaran pada belanja pegawai sebesar $0,26 \%$ atau sekitar 1,1 milyar dalam dua tahun anggaran. 
3. Hasil dari review alokasi yang dilakukan terhadap realisasi anggaran belanja daerah, terjadi penghematan anggaran belanja tahun 2017 sebesar 346 milyar rupiah dan pada tahun 2018 sebesar 317 milyar rupiah sehingga rata-rata penghematan anggaran di Kabupaten Sleman dalam periode dua tahun anggaran tersebut adalah sekitar 331,5 milyar rupiah

4. Untuk review tolak ukur dan kinerja dalam pelayanan dasar melalui layanan kesehatan dan Pendidikan, dimana untuk realisasi anggaran pada layanan kesehatan sebesar 91,06\% dapat tercapai kinerja sebesar $101,16 \%$ dan untuk layanan Pendidikan realisasi anggaran sebesar 79,08\% tercapai kinerja sebesar 103,41\%. Dari realisasi anggaran belanja tersebut menghasilkan peningkatan angka indeks pembangunan manusia dari $82,85 \%$ pada tahun 2017 menjadi 83,42\% di tahun 2018.

5. Analisis Deviasi Kebutuhan menunjukkan dalam dua tahun anggaran Pemerintah Kabupaten Sleman yakni tahun 2017 dan 2018 memiliki tingkat rata-rata deviasi kebutuhan dengan alokasi anggaran belanja daerah sebesar $(11,85 \%)$ atau sebesar 250,65 milyar rupiah.

\section{DAFTAR PUSTAKA}

Afrizal. (2015). Metode Penelitian Kualitatif: Sebuah Upaya Mendukung Penggunaan Penelitian Kualitatif dalam Berbagai Displin Ilmu. Jakarta: Raja Grafindo Persada.

Anggito, A., \& Setiawan, J. (2018). Metodologi Penelitian Kualitatif (First Edit; Ella Deffi Lestari, ed.). Jawa Barat: CV. Jejak Publisher.

Astutiningrum, A., Djamhuri, A., \& Prihatiningtias, Y. W. (2014). New Institutional Theory: Implementasi Anggaran Berbasis Kinerja Menuju Organisasi Yang Kompetitif Dan Berorientasi Pasar. Jurnal Reviu Akuntansi Dan Keuangan, 4(2), 595-606.

Creswell, J. . (2015). Penelitan Kualitatif \& Desain Riset: Memilih Di Antara Lima Pendekatan. Edisi Ke-3. Yogyakarta: Pustaka.

Dwiputrianti, S. (2012). Terhadap Efisiensi, Efektifitas Dan Akuntabilitas Pada Pusat Pendidikan Dan Pelatihan Kementerian Dalam. Jurnal STIA LAN Bandung, 9, 309-329.

Juanda, B., \& Heriwibowo, D. (2016). Melalui Reformasi Kebijakan Belanja Daerah Berkualitas (Decentralization Fiscal Consolidation through Policy Reform of Local Quality Spending). Jurnal Ekonomi \& Kebijakan Publik, 7(1), 15-28.

Khaerah, N., \& Mutiarin, D. (2016). Integrasi Anggaran Responsif Gender Dalam Anggaran Pendapatan Belanja Daerah (Studi Pada Anggaran Dinas Kesehatan Kota Makassar Tahun Anggaran 2014). Jurnal Ilmu Pemerintahan \& Kebijakan Publik, 3(3).

Kurrohman, T. (2013). Evaluasi Penganggaran Berbasis Kinerja Melalui Kinerja Keuangan Yang Berbasis Value For Money Di Kabupaten/Kota Jawa Timur. Jurnal Dinamika Akuntansi, 5(1), 1-11.

Ledo, D., \& Ayem, S. (2017). Pengaruh Aspek-Aspek Manajemen Keuangan Daerah Terhadap Transparansi Pengelolaan Keuangan Daerah (Studi Kasus Pada SKPD Kota Yogyakarta). Jurnal Kajian Bisnis, 25(2), 226-234.

Luthfia, M., \& Siregar, B. (2016). How Do Governments Spend Their Public Spending? Economia, 12(2), 135-145. 
ISSN 2088-7469 (Paper) ISSN 2407-6864 (Online)

Volume 10 Nomor 2 (2020)

Mujiono, M. I., \& Mutiarin, D. (2019). Implementasi penggunaan dana desa di kabupaten kota waringin barat tahun 2016. Journal of Governance and Local Politics, Vol: 1, No, 49-63.

Nanda, R., \& Darwanis. (2016). Analisis Implementasi Anggaran Berbasis Kinerja Pada Pemerintah Daerah (Studi Deskriptif Pada Dinas DPKKD Kabupaten Aceh Selatan). Jurnal Ilmiah Mahasiswa Ekonomi Akuntansi (JIMEKA), 1(1), 327-340.

Octariani, D. (2017). Good Governance, Performance Based Budgeting and SKPD Budget Quality SKPD ( The Case of a Structural Model Approach ). 21(November), 117-131.

Parhusip, B. (2016). Analisis Implementasi Spending Review pada Kementerian Negara/Lembaga Tahun 2013-2015. Kajian Ekonomi Keuangan Vol. 20 No 3 (Desember 2016), 20(3).

Prakoso, R. (2017). Indonesia Spending Reviews in the Context of Financial Management Reform. (December).

Pratama, N. D., Abdurahim, A., \& Sofyani, H. (2018). Determinan Efektivitas Implementasi Anggaran Berbasis Kinerja Dan Penyerapan Anggaran Di Pemerintah Daerah. Jurnal Reviu Akuntansi Dan Keuangan, 8(1), 9. https://doi.org/10.22219/jrak.v8i1.23

Rachmandiansyah, A. (2015). Analisis Spending Review Sebagai Keputusan Manajerial Sesuai Surat Edaran Direktur Jenderal Perbendaharaan Nomor SE-2 / PB / 2015. Jurnal Ilmiah Mahasiswa FEB, 6(2), 1-10.

Robinson, M. (2013). Spending review. OECD Journal on Budgeting, 13(2), 81-122.

Robinson, M., \& Last, D. (2009). Analisis Implementasi Anggaran Berbasis Kinerja Pada Pemerintah Daerah (Studi Deskriptif Pada Dinas DPKKD Kabupaten Aceh Selatan). Washington: International Monetary Fund.

Safaruddin, \& Basri, S. (2016). Pengaruh Penerapan Anggaran Berbasis Kinerja Terhadap Akuntabilitas Publik Pada Instansi Pemerintah (Studi Pada Badan Pengelola Keuangan Dan Aset Daerah Kota Kendari). Jurnal Akuntansi Dan Keuangan, 1(1), 93-105.

Sari, N. M. D. P., \& Mustanda, I. K. (2019). Pengaruh Ukuran Pemerintah Daerah, Pendapatan Asli Daerah Dan Belanja Modal Terhadap Kinerja Keuangan Pemerintah Daerah. E-Jurnal Manajemen Universitas Udayana, 8(8), 4759. https://doi.org/10.24843/ejmunud.2019.v08.i08.p02

Setiawan, D. (2017). Fenomena Plypaper Efect Pada Belanja Daerah Kabupaten/Kota Di Indonesia. EKUITAS (Jurnal Ekonomi Dan Keuangan), 1(2), 22. https://doi.org/10.24034/j25485024.y2017.v1.i2.2062

Sigiro, B. (2016). Responsivitas Anggaran ( Sebuah Refleksi dari Proses Penyusunan APBD. 571-596.

Silalahi, S. P. (2013). Pengaruh Anggaran Berbasis Kinerja, Sistem Akuntansi Keuangan Daerah, Dan Sistem Informasi Pengelolaan Keuangan Daerah Terhadap Penilaian Satuan Kerja Perangkat Daerah (Studi Pemerintahan Di Kota Dumai). Jurnal Ekonomi, 20(03), 1-20.

Sudaryanti, D. (2013). Pengaruh Penganggaran Terhadap Kinerja Aparat Pemda Melalui Sistem Informasi Keuangan Daerah (Studi Kasus: Pemda Kab Kudus). Jurnal Ekonomi Dan Bisnis, 12(1), 11-24. 
ISSN 2088-7469 (Paper) ISSN 2407-6864 (Online)

Volume 10 Nomor 2 (2020)

Verasvera, F. (2016). Pengaruh Anggaran Berbasis Kinerja Terhadap Kinerja Aparatur Pemerintah Daerah (Studi Kasus Pada Dinas Sosial Provinsi Jawa Barat). Jurnal Manajemen Maranatha, 15(2), 137-162.

Wijayanti, A. W., Rahman, M. R. K., \& Nurpratiwi, R. (2012). Perencanaan Anggaran Berbasis Kinerja di Kabupaten Pasuruan. Wacana, Jurnal Sosial Dan Humaniora, 15(3), 10-17. 